\title{
Contamination of Escherichia coli Drinking Water Refills on Drinking Water Depots in Malang City
}

\author{
WIWIK KUSMAWATI ${ }^{1 *}$, LIA RAHAYU ${ }^{1}$ \\ ${ }^{1}$ Department of Biology Education, Faculty of Exact Sciences and Sports, IKIP Budi Utomo Malang \\ Jl. Simpang Arjuno 14B, Malang, East Java, Indonesia. 65119 \\ *Email: wiwikkusmawati@gmail.com
}

Received 20 August 2018; Received in revised form 13 September 2018;

Accepted 19 February 2019; Available online 30 June 2019

\begin{abstract}
Data from the Malang City Health Office shows the increasing number of refill drinking water depots in the city of Malang until 2013 there were 163 drinking water depots scattered in each Malang Subdistrict. The purpose of this study was to determine the contamination of Escherichia coli refill drinking water in drinking water depots in Malang. The samples taken were 20 refill drinking water depots in Malang. Sampling is done by simple random sampling. Escherichia coli examination using the Most Probable Number Test. Of the 20 samples tested, 2 samples met the requirements of drinking water quality according to PERMENKES and 18 other samples containing the number of coliform bacteria exceeding the maximum limit of 0 per $100 \mathrm{ml}$ of water. There were Escherichia coli in 10 samples while 8 other samples contained other coliform bacteria.
\end{abstract}

Keywords: contamination; drinking water depot; Escherichia coli; refill drinking water

\section{INTRODUCTION}

Water is a chemical compound whose function is very important for the lives of human beings and other living things (Mukaromah \& Yusrin, 2010). Water needed by humans includes clean and healthy water for use in cooking, washing, and bathing, also as suitable consumption for drinking purposes (Rahayu, 2010). Water can also act as a medium for disease transmission (Prüss et al., 2002; Ashbolt, 2004). Water is a medium and environment which good for microorganisms habitat, both pathogenic and non-pathogenic microorganisms, therefore arises waterborne disease (Asfawi, 2004; Figueras \& Borrego, 2010).

Drinking water is water that goes through processing or without processing that meets health requirements and can be drunk directly. Drinking water is safe for health if it meets physical, microbiological, chemical, aesthetic and radioactive requirements (Szewyk et al., 2000; Dietrich, 2006; Hijnen et al., 2006). The mandatory parameters for microbiological drinking water quality determination are the total coliform bacteria, which are 0 per $100 \mathrm{ml}$ of water and Escherichia coli.
Meeting the community's drinking water needs varies greatly. In big cities, in terms of fulfilling drinking water needs, the community also consumes refill drinking water depots. Judging from the price of refill drinking water is cheaper than bottled drinking water, some even set prices up to $1 / 4$ of the price of bottled drinking water. Although in terms of quality, people still doubt because there is no clear information in terms of the process and regulations regarding circulation and supervision.

Various previous studies in various major cities in Indonesia showed refill drinking water was less safe or contaminated with bacteria that could harm human health. Research conducted by the Bogor Agricultural Institute and the Food and Drug Supervisory Agency stated that most of the drinking water products produced by refill drinking water depots did not meet the bottled drinking water industry standards. The research was conducted in several major cities such as Jakarta, Bandung, Medan, and Surabaya. The results of these two institutions showed that refill drinking water was contaminated with coliform bacteria, Escherichia coli, Salmonella sp., and even 
detected water samples containing heavy metal cadmium (Rubaiah, 2005).

One of the diseases caused by drinking water with poor microbiological quality is diarrhea (Wandrivel et al., 2012). Diarrhea is a prominent disease in the city of Malang with 34.322 cases in 2012 (East Java Provincial Health Office, 2013). Data from the Malang City Health Office shows the increasing number of refill drinking water depots in Malang City, until 2013 there were 163 drinking water depots scattered in each Kota Malang District (Malang City Health Office, 2015). Thus, this study aims to determine the contamination of Escherichia coli refill drinking water at drinking water depots in Malang, East Java province.

\section{MATERIALS AND METHODS}

The research conducted is descriptive laboratory. The sample in this study were 20 refill drinking water depots in the city of Malang. Sampling is done by simple random sampling. Microbiology examination using the Most Probable Number Test consisting of presumptive test using Lactose Broth (LB) medium, confirmative test using Brilliant
Green Lactose Broth medium (BGLBB) and complete test using agar EMB.

\section{RESULT AND DISCUSSION}

Refill drinking water samples obtained from refill drinking water depots in Malang city were 20 samples. Microbiology examination using the Most Probable Number Test. The first stage is presumptive test using Lactose Broth (LB) medium because it is a medium to detect the presence of coliform bacteria. A positive result is indicated by the formation of gas in a durham tube and is acidic when the media turns yellow. In the medium of Lactose Broth (LB) contains peptone and meat extracts which provide important nutrients for bacterial metabolism. Lactose contained also provides a source of carbohydrates that can be fermented by coliform bacteria.

Samples that showed positive results in the presumption test were followed by a confirmation test to determine the total Escherichia coli using BGLB media. Total Escherichia coli in refill drinking water using Brilliant Green Lactose Broth (BGLB) media can be seen in table 1 as follows:

Table 1. Total Escherichia coli in refillable drinking water using Brilliant Green Lactose Broth (BGLB) media

\begin{tabular}{ccccc}
\hline \multirow{2}{*}{ Sample } & \multicolumn{1}{c}{ Dilution Level } & MPN Index/100 $\mathbf{~ m l}$ \\
\cline { 2 - 4 } & 3 & $\mathbf{1 ~} \mathbf{~ m l}$ & $\mathbf{0 . 1} \mathbf{~ m l}$ & 93 \\
\hline 1 & 3 & 2 & 0 & 39 \\
\hline 2 & 3 & 0 & 1 & 64 \\
\hline 3 & 2 & 1 & 2 & 15 \\
\hline 4 & 3 & 0 & 0 & 23 \\
\hline 5 & 3 & 0 & 2 & 64 \\
\hline 6 & 2 & 2 & 1 & 28 \\
\hline 7 & 3 & 0 & 1 & 39 \\
\hline 8 & 2 & 1 & 1 & 20 \\
\hline 9 & 3 & 0 & 1 & 39 \\
\hline 10 & 2 & 2 & 1 & 28 \\
\hline 11 & 3 & 0 & 1 & 39 \\
\hline 12 & 2 & 1 & 1 & 39 \\
\hline 13 & 3 & 0 & 1 & 0 \\
\hline 14 & 0 & 0 & 0 & 64 \\
\hline 15 & 2 & 1 & 1 & 28 \\
\hline 16 & 3 & 0 & 2 & 15 \\
\hline 17 & 2 & 2 & 1 & 0 \\
\hline 18 & 2 & 1 & 0 & \\
\hline 19 & 0 & 0 & 0 & \\
\hline 20 & & & & \\
\hline
\end{tabular}


Based on the examination of the number of coliform bacteria contamination in refill drinking water above shows that as many as 18 samples from 20 samples tested were contaminated with coliform bacteria.

Samples that gave positive results in the presumptive test were inoculated on agar EMB media and incubated at $35^{\circ} \mathrm{C}$ for 24 hours. EMB agar test media is a differentiation medium for isolation of coliform bacteria. The presence of Escherichia coli is characterized by blackish purple colonies in the middle and metallic luster and 2-3 $\mathrm{mm}$ in diameter. Refill drinking water samples were tested, the results of inoculation on the EMB to provide varied results as in table 2.

Table 2. Results of inoculation on the agar EMB

\begin{tabular}{cllc}
\hline No. & Sample & \multicolumn{1}{c}{ Colonies on EMB agar } & Information \\
\hline 1 & Sample 1 & Colonies with metallic luster & E.coli \\
\hline 2 & Sample 2 & Colonies with metallic luster & E.coli \\
\hline 3 & Sample 3 & Colonies with metallic luster & E.coli \\
\hline 4 & Sample 4 & Colonies with metallic luster & E.coli \\
\hline 5 & Sample 5 & Colonies with metallic luster & E.coli \\
\hline 6 & Sample 6 & Pink colony & Pseudomonas \\
\hline 7 & Sample 7 & Blackish purple and mucoid pink colonies & Pseudomonas / Enterobacter \\
\hline 8 & Sample 8 & Colonies with metallic luster & Pseudomonas \\
\hline 9 & Sample 9 & Pink colony & Pseudomonas \\
\hline 10 & Sample 10 & Pink colony & E.coli \\
\hline 11 & Sample 11 & Colonies with metallic luster & E.coli \\
\hline 12 & Sample 12 & Colonies with metallic luster & Pseudomonas \\
\hline 14 & Sample 13 & Pink colony & Pseudomonas / Enterobacter \\
\hline 15 & Sample 14 & Pink-mucoid colony & Enterobacter \\
\hline 16 & Sample 15 & No inoculation & E.coli \\
\hline 17 & Sample 16 & Blackish purple and mucoid pink colonies & Pseudomonas / Enterobacter \\
\hline 19 & Sample 17 & Colonies with metallic luster & E.coli \\
\hline
\end{tabular}

Samples of 15 and 20 were not inoculated to the EMB hence it showed negative results in the presumptive test, then as many as 18 samples were tested and inoculated in the EMB. The results of 10 samples of refill drinking water showed colonies with metallic luster. EMBs contain eosin and methylene blue which can inhibit the growth of gram-positive bacteria and support the growth of gram-negative bacteria. In addition, lactose contained and fermented by bacteria will produce colonies with dark nuclei which indicate acid production. Escherichia coli is a bacteria that can ferment lactose quickly and produce acid (Fong et al., 2005; Edberg et al., 2012; Rosales-Colunga et al., 2012). Metallic luster produced by colonies due to deposits of metallic green pigments (Ranjbar et al., 2014). The presence of Escherichia coli in refill drinking water indicates the possibility of contamination as well as the presence of enteropathogenic microbes that can disrupt human health.

Factors that might cause positive results from the MPN presumptive test are the occurrence of contamination of refill drinking water in the processing process, including raw water storage, disinfection, and filtration (Dechesne \& Soyeux, 2007). In addition, sanitation and hygiene from refill drinking water depots can affect the MPN test results. Poor sanitation and low hygiene cause contamination. Based on observations from refill drinking water depots, the samples of this study have poor sanitation and hygiene, also the disinfection process of containers did not meet the requirements. These can explain why the MPN results on samples of refill drinking water from the depot are high-positive result. 


\section{CONCLUSION}

Based on the result of 20 samples tested, 2 samples met the requirements of drinking water quality according to PERMENKES and 18 other samples containing the number of coliform bacteria exceeding the maximum limit of 0 per $100 \mathrm{ml}$ of water. There were E. coli in 10 samples while other samples contained coliform bacteria.

\section{ACKNOWLEDGMENTS}

The authors would like to thank Kemenristekdikti for providing financial support for this research.

\section{REFERENCES}

Ashbolt NJ. 2004. Microbial contamination of drinking water and disease outcomes in developing regions. Toxicology. vol 198(13): 229-238. doi: https://doi:.org/10.1016/j.tox.2004.01.030.

Asfawi S. 2004. analisis faktor yang berhubungan dengan kualitas bakteriologis air minum isi ulang pada tingkat produsen di Kota Semarang. [Tesis]. Semarang: Universitas Diponegoro.

Dechesne M, Soyeux E. 2007. Assessment of source water pathogen contamination. Journal of Water and Health. vol 5 (S1): 39-50.

doi https://doi.org/10.2166/wh.2007.133.

Dietrich AM. 2006. Aesthetic issues for drinking water. Journal of Water and Health. Vol 4(S1): 11-16. doi: https://doi.org/10.2166/wh.2006.0038

Dinas Kesehatan Provinsi Jawa Timur. 2013. Profil Kesehatan Provinsi Jawa Timur Tahun 2012. Surabaya: Dinkes Jawa Timur. hal 1-70.

Dinas Kesehatan Kota Malang. 2015. Profil Kesehatan Kota Malang Tahun 2014. Malang: Dinkes Kota Malang.

Edberg SC, Rice EW, Karlin RJ, Allden MJ. 2012. Escherichia coli: the best biological drinking water indicator for public health protection. Journal of Applied Microbiology. vol 88(S1): 106S-116S. doi: https://doi.org/10.1111/j.1365-

2672.2000.tb05338.x.
Figueras MJ, Borrego JJ. 2010. New perspectives in monitoring drinking water microbial quality. International Journal of Environmental Research and Public Health. vol 7(12): 4179-4202. doi: https://doi.org/10.3390/ijerph7124179.

Fong SS, Burgard AP, Hering CD, Knight EM, Blattner FR, Maranas CD, Palsson BO. 2005. In silico design and adaptive evolution of Escherichia coli for production of lactic acid. Biotechnology and Bioengineering. vol 91(5): 643-648. doi: https://doi.org/10.1002/bit.20542.

Hijnen WAM, Beerendonk EF, Medema GJ. 2006. Inactivation credit of UV radiation for viruses, bacteria and protozoan (oo)cysts in water: A review. Water Research. vol 40(1): 3-22. doi: https://doi.org/10.1016/j.watres.2005.10.0 30.

Mukaromah AH and Yusrin. 2010. Pengaruh lama waktu simpan pada suhu ruang (27$29^{\circ} \mathrm{C}$ ) terhadap kadar zat organik pada air minum isi ulang. Prosiding Seminar Nasional Unimus. 12-13 Mei 2015. Semarang: LPPM Universitas Muhammadiyah Semarang. ISBN 978.979.704.883.9.

Prüss A, Kay D, Fewtrell L, Bartram J. 2002. Estimating the burden of disease from water, sanitation, and hygiene at a global level. Environmental Health Perspectives. waterborne 110(5): 537-542. doi: https://doi.org/10.1289/ehp.110-1240845.

Rahayu A. 2010. Deteksi adanya bakteri pada air minum dalam galon. Jurnal Ilmiah Kedokteran Wijaya Kusuma. vol 2(1): 1-6.

Ranjbar R, Ahmadnezhad B, Jonaidi N. 2014. The prevalance of beta lactamase producing Escherichia coli strains isolated from the urine samples in valiasr hospital. Biomedical \& Pharmacology Journal. vol 7(2): 425-431. doi: http://dx.doi.org/10.13005/bpj/507.

Rosales-Colunga LM, Razo-Flores E, Rodríguez ADL. 2012. Fermentation of lactose and its constituent sugars by Escherichia coli WDHL: Impact on hydrogen production. Bioresource Technology. Vol 111: 180-144. 
https://doi.org/10.1016/j.biortech.2012.01. 175

Rubaiah A. 2005. Pengaruh nilai produk yang dirasakan terhadap proses keputusan pembelian konsumen air minum isi ulang pada depot Aloa Bandung. [Tesis]. Bogor: Institut Pertanian Bogor.

Szewyk U, Szewzyk R, Manz W, Schleifer KH. 2000. Microbiological Safety of Drinking Water. Annual Review of Microbiology. vol 54: 81-127. doi: https://doi.org/10.1146/annurev.micro.54. 1.81 .

Wandrivel R, Suharti N, and Lestari Y. 2012. Kualitas air minum yang diproduksi di depot air minum isi ulang di kecamatan Bungus Padang berdasarkan persyaratan mikrobiologi. Jurnal Kesehatan Andalas. vol 1(3): 129-133. 